\title{
Pengukuran Sistem Karbon Dioksida (Co2) Sebagai Data Dasar Penentuan Fluks Karbon Di Perairan Jepara
}

\author{
Indra Budi Prasetyawan*, Lilik Maslukah, Azis Rifai \\ Departemen Oseanografi, Fakultas Perikanan dan Ilmu Kelautan, Universitas Diponegoro \\ Kampus Tembalang, Semarang 50275 Telp/Fax. 024-7474698 \\ Email: indrabudiprasetyawan2016@gmail.com
}

\begin{abstract}
Abstrak
Sistem $\mathrm{CO}_{2}$ dalam perairan adalah dalam bentuk gas $\left(\mathrm{CO}_{2}\right)$, asam bikarbonat, ion bikarbonat dan ion karbonat. Jumlah total dari semua bentuk sistem $\mathrm{CO}_{2}$ disebut konsentrasi total $\mathrm{CO}_{2}\left[\sum \mathrm{CO}_{2}\right]$ dan sering disebut karbon anorganik terlarut (Dissolved Inorganic Carbon/DIC). Keberadaan karbon anorganik ini berperan penting dalam reaksi kimiawi di dalam perairan. Pertukaran (fluks) karbon anorganik juga berperan penting dalam mengontrol $\mathrm{pH}$ di laut dan juga menentukan perairan sebagai source karbon (sumber) atau sink karbon (penyimpan). Perbedaan tekanan parsial karbon menentukan pertukaran antara atmosfir dan lautan. Untuk mengetahui variabilitas pertukaran $\mathrm{CO}_{2}$ antara laut dan atmosfer diperlukan pengukuran sistem $\mathrm{CO}_{2}$. Tujuan utama dari penelitian ini adalah mengkaji distribusi spasial karbon anorganik terlarut di Perairan Jepara dan hubungannya dengan faktor-faktor fisika-kimia perairan yang meliputi suhu, $\mathrm{pH}$, alkalinitas, salinitas dan DO. Metode penelitian yang digunakan dalam penelitian ini adalah kuantitatif. Pengukuran karbon anorganik terlarut, alkalinitas dan oksigen terlarut menggunakan metode titrasi. Hasil analisa data ditampilkan dalam bentuk peta sebaran dengan menggunakan program ArGIS. Berdasarkan hasil penelitian di Perairan Jepara diperoleh kesimpulan sebagai berikut bahwa semua stasiun kecuali stasiun 11 memiliki nilai temperatur berkisar antara $29-30^{\circ} \mathrm{C}$, hal ini dikarenakan pengukuran berada di perairan terbuka dan dekat dengan daratan sehingga energi matahari lebih efektif meningkatkan temperatur air laut. Nilai salinitas terendah berada di Stasiun 1 yang letaknya berada di mulut muara Sungai Serang dengan nilai $28.7 \%$, hal ini di karenakan adanya masukan air tawar yang memiliki salinitas yang rendah.Kandungan DO yang rendah berkisar $2.4 \mathrm{ppm}-2.56$ ppm dikarenakan masuknya bahan-bahan organik ke perairan Jepara sehingga membutuhkan oksigen yang banyak untuk menguraikannya.Dari hasil analisis di laboratorium terhadap 12 sampel air laut Perairan Jepara, menunjukkan bahwa kandungan $\mathrm{CO}_{2}$ berkisar antara $4.6 \mathrm{ppm}-24.1 \mathrm{ppm}$. Stasiun 1 dan Stasiun 2 yang terletak di dekat muara Sungai Serang memiliki kandungan $\mathrm{CO}_{2}$ yang lebih besar dibandingkan Stasiun-Stasiun lainnya.
\end{abstract}

Kata Kunci: $\mathrm{CO}_{2}$, Karbon Anorganik, Fisika-Kimia Perairan

\begin{abstract}
$\mathrm{CO} 2$ in the water system is in gaseous form (CO2), the bicarbonate acid, bicarbonate ions and carbonate ions. The total amount of all forms of the CO2 system called total concentration of CO2 [ [ $\mathrm{CO} 2]$ and is often called the dissolved inorganic carbon (Dissolved Inorganic Carbon / DIC). The existence of inorganic carbon plays an important role in the chemical reactions in the water. Exchange (flux) inorganic carbon is also important in controlling $\mathrm{pH}$ in the ocean and also determines the waters as a source of carbon (sources) or a carbon sink (storage). Differences partial pressure of carbon determines the exchange between the atmosphere and oceans. To determine the variability of the exchange of $\mathrm{CO} 2$ between the ocean and atmospheric CO2 system measurement required. The main objective of this study is to examine the spatial distribution of dissolved inorganic carbon in the waters of Jepara and its association with factors physico-chemical marine waters of $p H$, alkalinity, salinity and chlorophyll. The method used in this research is quantitative. Measurement of dissolved inorganic carbon, alkalinity and dissolved oxygen using titration methods. Results of analysis of the data shown in the form of distribution maps using ARGIS program. Based on the result of research of Jepara Waters, inferred that all Stations except Station 11 has temperature value ranged $29-30^{\circ} \mathrm{C}$, it is caused that the measurements conducted in open ocean and close to land therefore sun energy more effective to increase sea water temperature. The lowest salinity at the Station 1 located at the mouth of Serang River is $28.7 \%$, it is caused by the existence of river discharge which has low salinity. The low DO ranged 2.4 ppm - 2.56 ppm
\end{abstract}

\footnotetext{
*Corresponding author

buloma.undip@gmail.com

http://ejournal.undip.ac.id/index.php/buloma

Diterima/Received : 10-11-2016

Disetujui/Accepted : 18-12-2016
} 
caused by the input of organic materials into Jepara Waters. According to analysis result at the laboratorium to 12 water samples in the Jepara Waters, showing the value of $\mathrm{CO}_{2}$ ranged from $4.6 \mathrm{ppm}-24.1 \mathrm{ppm}$. Station 1 and Station 2 that are located at the river mouth contain higher $\mathrm{CO}_{2}$ than the other stations.

Keywords: $\mathrm{CO}_{2}$, Inorganic Carbon, Physics-Chemistry Waters

\section{PENDAHULUAN}

Pemanasan global merupakan isu yang paling banyak mendapat perhatian pada saat ini. Gas-gas rumah kaca $\left(\mathrm{CO}_{2}, \mathrm{CH}_{4}, \mathrm{~N}_{2} \mathrm{O}\right.$, dan $\left.\mathrm{CF}_{4}\right)$ merupakan salah satu penyebab terjadinya pemanasan global (IPCC, 2001). Gas-gas rumah kaca di atmosfir bumi ini telah menyebabkan kenaikan suhu global serta perubahan pola curah hujan (IPCC, 2007). $\mathrm{CO}_{2}$, menjadi gas rumah kaca utama, yang mendapat perhatian lebih besar di seluruh dunia, karena keterlibatannya dalam siklus biogeokimia wilayah pesisir dan laut terbuka (Takahashi et al., 2002; Borges, 2005; Borges et al.,2005).

Pemanasan global yang terjadi belakangan ini sebagai akibat meningkatnya emisi gas karbon ke atmosfer telah mengakibatkan peningkatan suhu udara maupun suhu air laut secara nyata. Sistem pesisir merupakan suatu sistem yang kompleks karena adanya variasi temporal dan spasial. Sistem pesisir bisa bersifat heterotrofik ataupun autotrofik. Bersifat heterotrofik karena perairan pesisir menerima pasokan material organik dari daratan, sedangkan bersifat autotrofik karena banyaknya pasokan nutrien dari darat maupun dari proses upwelling. Dalam banyak sistem, perairan estuari adalah heterotrofik karena besarnya pasokan partikel organic karbon (POC) yang berasal dari daratan. Dalam sistem ini, air selalu sangat jenuh terhadap $\mathrm{CO}_{2}$ di mana tekanan parsial $\mathrm{CO} 2\left(p \mathrm{CO}_{2}\right)$ sering lebih tinggi dari $1500 \mu$ atm dan bahkan melebihi $4000 \mu \mathrm{atm}$ di sungai tercemar (Chen et al.,2006). Penyerapan $\mathrm{CO}_{2}$ oleh perairan laut dan pesisir terjadi melalui dua mekanisme yaitu pompa daya larut (solubility pump) dan pompa biologis (biological pump). Pompa daya larut dibangkitkan oleh pertukaran gas antar permukaan udara-laut dan proses-proses fisis yang membawa $\mathrm{CO}_{2} \mathrm{ke}$ dalam laut. $\mathrm{CO}_{2}$ atmosferik masuk ke laut melalui pertukaran gas yang bergantung pada kecepatan angin dan perbedaan tekanan parsial $\mathrm{CO}_{2}$ udaralaut.

Data menunjukkan bahwa perairan pesisir di daerah temperatur dan lintang tinggi berperan sebagai sink $\mathrm{CO}_{2}$ dari atmosfir, sedangkan perairan pesisir di daerah subtropis dan tropis berperan sebagai source $\mathrm{CO}_{2}$ ke atmosfir (Borges, 2005; Wang \& Cai, 2004; Cai et al., 2006). Namun beberapa penelitian lain juga mencatat adanya perairan pesisir di daerah tropis yang berperan sebagai sink $\mathrm{CO}_{2}$ dari atmosfir, seperti yang ditunjukkan oleh Cai et al. (2006) bahwa muara Sungai Mississippi adalah sink $\mathrm{CO}_{2}$ dari atmosfir. Hal tersebut menunjukkan bahwa ekosistem perairan pesisir berperan penting dalam menentukan apakah perairan laut berperan sebagai source atau sink $\mathrm{CO}_{2}$. Untuk menentukan peran perairan sebagai source atau sink dapat diamati melalui tekanan parsial $\mathrm{CO}_{2}$ antara perairan dan atmosfer. Tekanan parsial $\mathrm{CO}_{2}$ di perairan dapat diperoleh melalui pengukuran system $\mathrm{CO}_{2}$. Parameter yang diperlukan dalam pengukuran sistem $\mathrm{CO}_{2}$ adalah konsentrasi carbon an organic total (DIC), $\mathrm{pH}$ dan alkalinitas. Data DIC diperlukan dalam perhitungan $\mathrm{pCO}_{2}$ (tekanan parsial) dan selanjutnya dapat dipakai sebagai dasar perhitungan fluks karbon. Tujuan dari penelitian ini adalah mengkaji distribusi spasial karbon anorganik terlarutdi Perairan Jepara dan hubungannya dengan faktor-faktor fisika-kimia perairan yang meliputi suhu, $\mathrm{pH}$, alkalinitas, salinitas dan DO.

\section{MATERI DAN METODE}

Materi penelitian berupa sampel air laut yang diambil dari stasiun penelitian di Jepara. Variabel yang diamati di setiap stasiun pengamatan adalah Dissolved In Organic Carbon (DIC), alkalinitas, salinitas, $\mathrm{Ph}$, klorofil, dan DO.Penentuan lokasi pengambilan data lapangan dilakukan secara purposive sampling (pertimbangan). Pengambilan sampel dilakukan di 12 stasiun dari lokasi penelitian yang mewakili beberapa wilayah pantai Perairan Jepara (Gambar 1).Pengambilan sampel air untuk sistem $\mathrm{CO}_{2}$ dilakukan pada lapisan permukaan $(0-1$ meter $)$ untuk semua stasiun dengan menggunakan Nansen water sample. Sesaat setelah pengambilan sampel, ditambahkan $\mathrm{HgCl}_{2}$ pada sampel air untuk menghentikan aktivitas biologi dan sampel disimpan dalam coolbox yang selalu ditambahkan es batu agar suhu tetap rendah untuk mencegah terlepasnya $\mathrm{CO}_{2}$ ke udara. Analisis lebih lanjut dilakukan di laboratorium.

Pada sebanyak 100 sampel ditambah 5 tetes pp (Phenolphthalein), selanjutnya titrasi dengan 
$0,1 \mathrm{~N} \mathrm{Na}_{2} \mathrm{CO}_{3}$ sampai larutan menjadi merah muda. Hasil penetapan kadar $\mathrm{CO}_{2}$ melalui persamaan berikut:

$\mathrm{Ppm} \mathrm{CO}_{2}=\left(\frac{1000}{\text { ml sampel }}\right)(\mathrm{ml}$ (titrasi)

(Normalitas $\mathrm{Na}_{2} \mathrm{CO}_{3}$ ) (22)

Alkalinitas Total diukur dengan menggunakan metode "titrasi" (Grasshoff, 1976). Prosedurnya sebagai berikut: Ke dalam $50 \mathrm{ml}$ sampel air laut ditambahkan $5 \mathrm{ml} \mathrm{HCl}$ 0,025 $\mathrm{M}$ dan dididihkan selama \pm 5 menit, kemudian didinginkan dalam water bath. Setelah dingin ke dalam sampel ditambahkan $3-5$ tetes bromothymol blue sebagai indikator, kemudian sampel dititrasi dengan $\mathrm{NaOH}$ 0,02 M, selama titrasi kedalam sampel dialirkan gas bebas $\mathrm{CO} 2$ (nitrogen atau helium). Proses titrasi dihentikan setelah sampel bewarna biru, dan volume $\mathrm{NaOH}$ yang terpakai dicatat dan dimasukkan ke dalam rumus berikut:

$$
\text { AlkTotal }=\frac{1000 \times v H C l \times t H C l}{v b}-\frac{1000 \times v N a O H \times t N a O H}{v b}
$$

Keterangan:

$\mathrm{V}=$ Volume $\mathrm{HCl}$ dan $\mathrm{NaOH}$

$\mathrm{t}=$ Molaritas $\mathrm{HCl}$ dan $\mathrm{NaOH}$

$\mathrm{Vb}=$ Volume sampel
Pengukuran kandungan Oksigen terlarut dilakukan dengan menggunakan metode titrasi Winkler. Data hasil pengukuran lapangan berupa suhu, salinitas, $\mathrm{pH}$, alkalinitas dan DO dibuat peta sebaran dengan menggunakan ArGIS. Data hasil pengukuran $\mathrm{CO}_{2}$ total di laboratorium juga dipetakan menggunakan ArGIS.

\section{HASIL DAN PEMBAHASAN Hasil Pengukuran Temperatur}

Pengukuran parameter temperatur air laut dilakukan di 12 titik stasiun yang sama dengan titik stasiun pengambilan sampel air. Temperatur yang diukur merupakan temperatur insitu permukaan yang diukur dengan menggunakan termometer. Hasil pengukuran di 12 titik stasiun digunakan untuk membuat peta pola sebaran temperatur di Perairan Jepara dengan menggunakan pendekatan interpolasi. Peta sebaran temperatur di Perairan Jepara diperlihatkan pada Gambar 4. Hasil pengukuran bahwa temperatur permukaan untuk 12 Stasiun pengukuran di Perairan Jepara antara $28^{\circ}$ C- $30^{\circ} \mathrm{C}$.

Semua stasiun kecuali stasiun 11 memiliki nilai temperatur berkisar antara $29-30^{\circ} \mathrm{C}$ hal ini dikarenakan pengukuran berada di perairan terbuka dan dekat dengan daratan sehingga energi matahari lebih efektif meningkatkan temperatur air laut. Hal ini seperti yang diungkapkan Suyarso (1997)

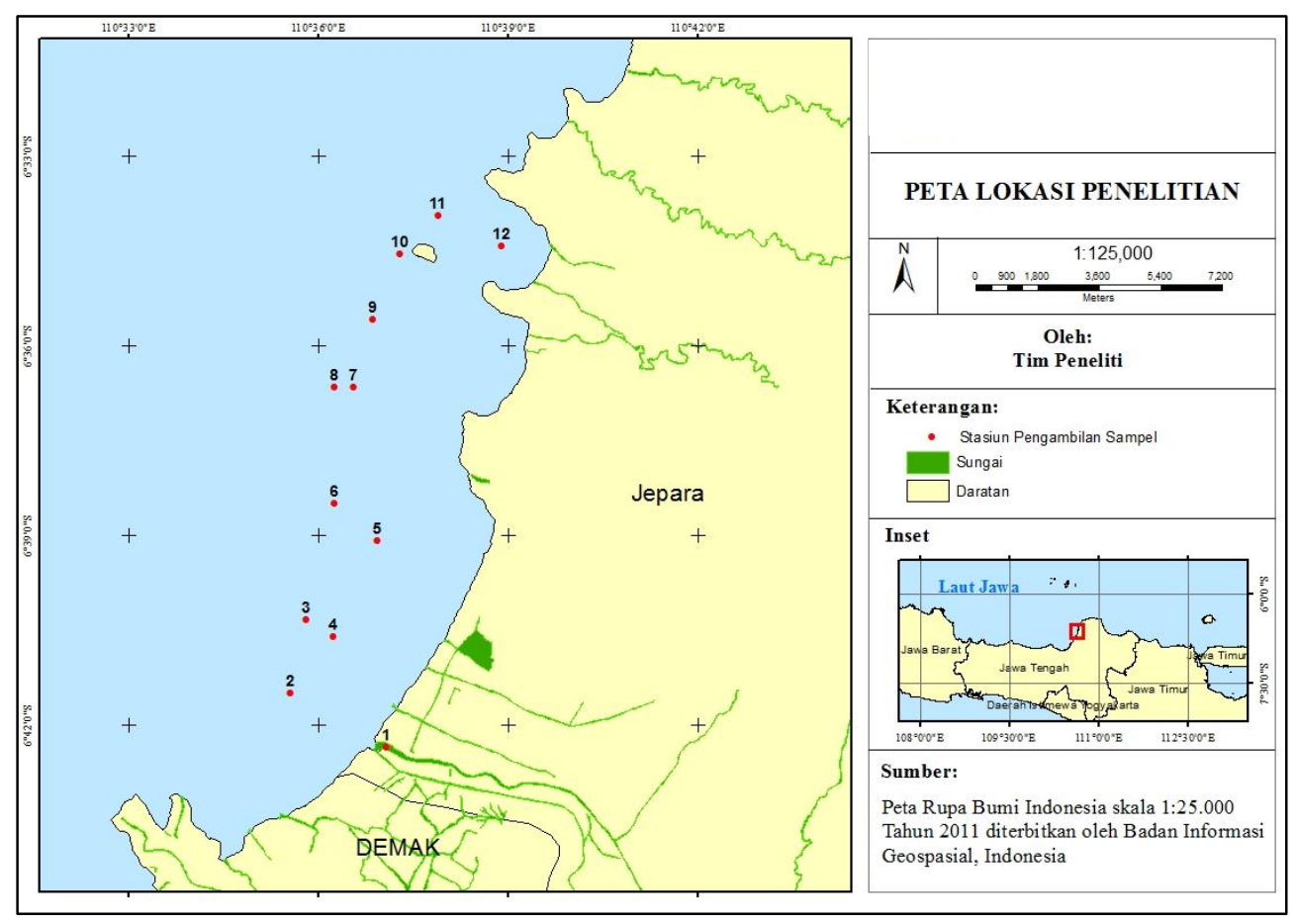

Gambar 1. Peta Lokasi Peneliti 
dalam Nababan dan Simamora (2012) bahwa di perairan pantai memiliki temperatur yang lebih tinggi dikarenakan adanya efek daratan yang lebih panas. Sedangkan temperatur terendah berada pada stasiun 11 yaitu sebesar $28,33^{\circ} \mathrm{C}$ yang berada di depan teluk dan di tengah-tengah antara daratan Jepara dan pulau kecil, hal ini kemungkinan terjadi karena adanya dorongan massa air laut dari lepas pantai menuju teluk. Stasiun 12 berada di dalam teluk namun nilai temperaturnya sebesar $29^{\circ} \mathrm{C}$ hal ini dikarenakan stasiun 12 lebih dekat dengan daratan dibandingkan dengan stasiun 11 dan adanya masukan air tawar yang lebih hangat dari sungai di dekat pengambilan sampel stasiun 12 .

\section{Hasil Pengukuran Salinitas}

Pengukuran salinitas air laut dilakukan juga di 12 titik stasiun yang sama dengan titik stasiun pengambilan sampel air. Salinitas diukur dengan menggunakan refraktometer. Salinitas yang terukur merupakan salinitas air laut di permukaan. Peta sebaran salinitas di Perairan Jepara hasil pengukuran dapat dilihat pada Gambar 5. Dari hasil pengukuran salinitas menunjukkan bahwa, nilai salinitas berkisar antara $28.7 \%$ - $32 \%$. Nilai salinitas terendah berada di Stasiun 1 yang letaknya berada di mulut muara Sungai Serang dengan nilai $28.7 \%$ hal ini di karenakan adanya masukan air tawar yang memiliki salinitas yang rendah. Nilai salinitas semua stasiun kecuali stasiun 1, 11 dan 12 memiliki nilai $30,67 \%$ - 32,33\% karena berada di perairan yang jauh dari muara sungai. Nilai salinitas di stasiun $12 \quad 29,67 \%$, dikarenakan terpengaruhi air tawar dari sungai di stasiun 12 .

\section{Hasil Pengukuran pH}

Pengukuran $\mathrm{pH}$ air laut dilakukan juga untuk sampel air laut di 12 titik stasiun. $\mathrm{pH}$ diukur dengan menggunakan alat pHmeter. Peta sebaran $\mathrm{pH}$ di Perairan Jepara hasil pengukuran dapat dilihat pada Gambar 6. Hasil pengukuran menunjukkan bahwa nilai $\mathrm{pH}$ berkisar antara $7.37-8.21$. Semua stasiun kecuali stasiun 1 memiliki kisaran $\mathrm{pH}$ yang kecil yaitu 7,96-8,21 hal ini sesuai dengan pernyataan Brotowidjoyo et al. (1995) bahwa pH relatif stabil pada perairan laut maupun pesisir dan berada pada kisaran yang kecil yaitu sebesar 7,6 - 8,3 yang bersifat basa. Sedangkan stasiun 1 yang berada di muara Sungai Serang sebesar 7,37 hampir mendekati $\mathrm{pH}$ normal hal ini karena mendapat masukan dari daratan yang yaitu limbah-limbah rumah tangga dan industri yang bersifat asam melalui sungai. Mackereth et al., (1989) mengungkapkan bahwa kondisi $\mathrm{pH}$ berkaitan erat dengan karbondioksidan dan alkalinitas hal ini dikarenakan semakin tinggi $\mathrm{pH}$ maka kadar karbondioksida akan semakin rendah berbeda dengan alkalinitas, semakin tinggi $\mathrm{pH}$ maka semakin tinggi nilai alkalinitas.

\section{Hasil Analisis Alkalinitas}

Analisis alkalinitas air laut dilakukan terhadap sampel air laut di 12 titik stasiun. Alkalinitas Total diukur dengan menggunakan metode titrasi dengan normalitas $0.02 \mathrm{~N}$. Hasil analisis di 12 titik stasiun tersebut digunakan untuk membuat peta pola sebaran alkalinitas di Perairan. Peta sebaran alkalinitas di Perairan Jepara diperlihatkan pada Gambar 5.

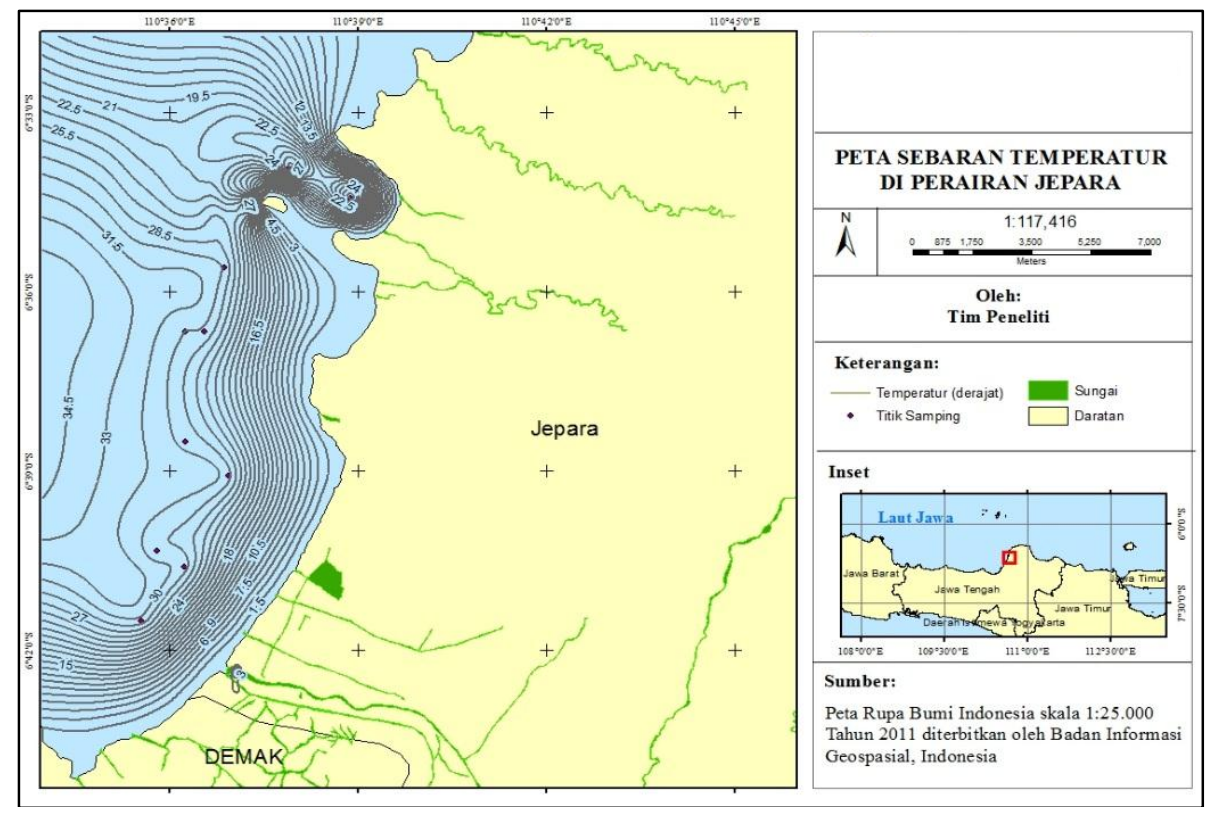

Gambar 2. Peta Sebaran Temperatur di Perairan Jepara. 


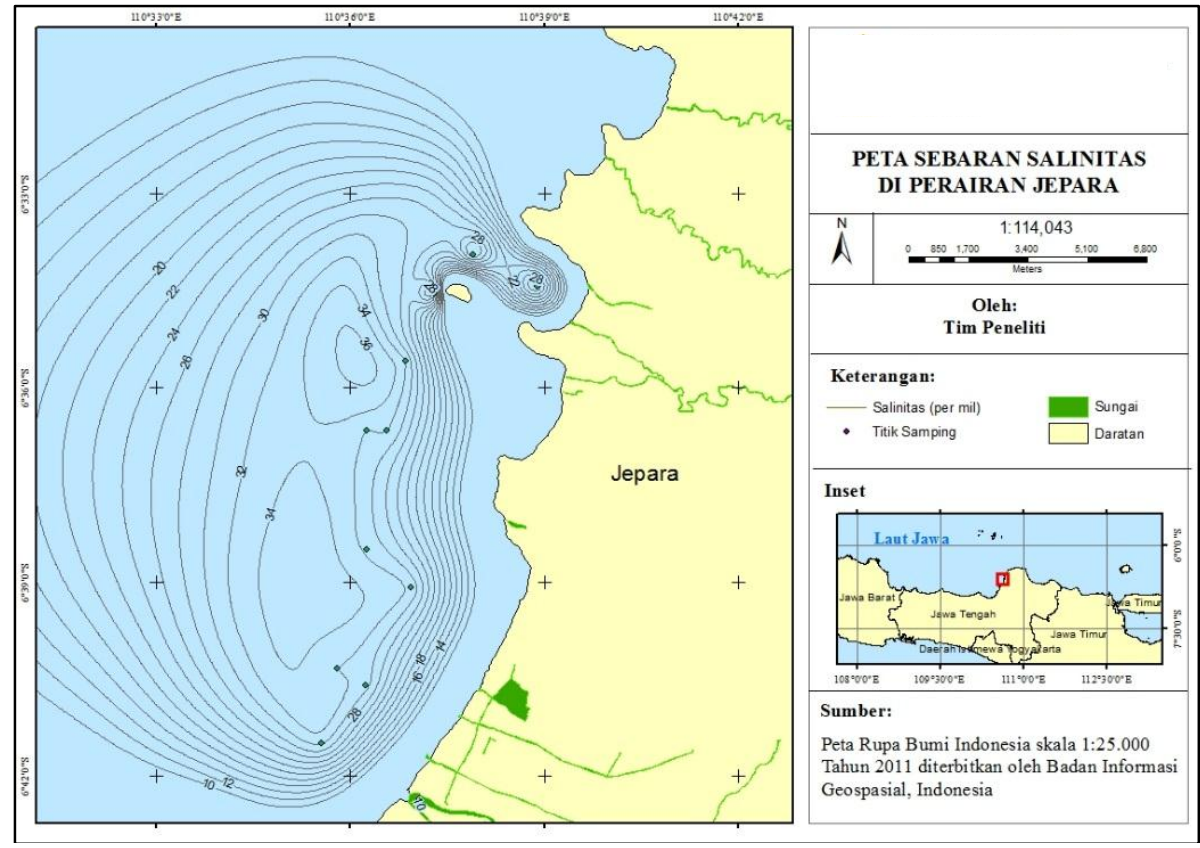

Gambar 3. Peta Sebaran Salinitas di Perairan Jepara

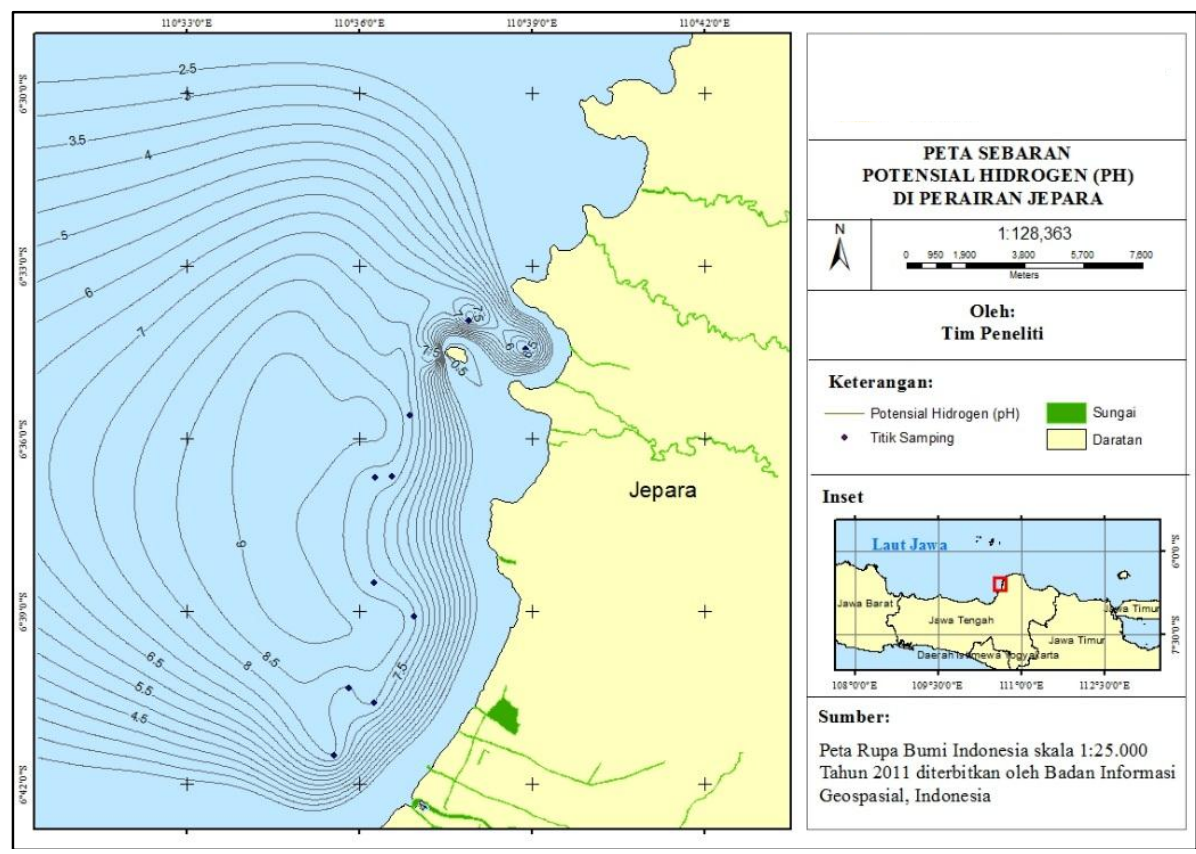

Gambar 4. Peta Sebaran pH di Perairan Jepara.

Hasil analisis laboratorium terhadap sampel air laut, menunjukkan bahwa nilai alkalinitas relatif tidak jauh berbeda. Nilai alkalinitas berkisar antara 120 - 130. Nilai alkalinitas terbesar berada di Stasiun 9, yaitu 130 .

Alkalinitas berkaitan erat dengan $\mathrm{pH}$ apabila nilai alkalinitas tinggi maka nilai $\mathrm{pH}$ akan semakin tinggi. Nilai alkalinitas yang tidak jauh berbeda menunjukkan bahwa perairan laut cenderung stabil dengan sifat basa. Nilai alkalinitas akan semakin berkurang apabila adanya masukan zat yang bersifat asam misalkan dari daratan melalui aliran sungai, seperti pada stasiun 12 memiliki nilai alkalinitas lebih kecil yaitu 120 dibandingkan dengan stasiun 9 yaitu 130. Hal ini dikarenakan stasiun 12 dipengaruhi oleh masukan dari daratan yang berasal dari sungai kecil di wilayah tersebut, sedangkan stasiun 9 berada jauh dari muara sungai.

\section{Hasil Analisis Dissolved Oxygen (DO)}

Analisis DO air laut dilakukan terhadap sampel air laut di 12 titik stasiun. DO diukur dengan menggunakan metode titrasi dengan normalitas $0.02 \mathrm{~N}$. Namun demikian, sampel yang 
dapat dianalisis hanya bisa dilakukan untuk delapan sampel. Hal ini diduga diakibatkan terjadi kesalahan perlakuan pada empat sampel yang tidak bisa dilakukan analisis. Hasil analisis sampel tersebut digunakan untuk membuat peta pola sebaran DO di Perairan. Peta sebaran DO di Perairan Jepara diperlihatkan pada Gambar 6.

Berdasarkan hasil analisis laboratorium terhadap sampel air laut, terlihat bahwa kandungan DO relatif tidak jauh berbeda. Kandungan DO sedikit lebih besar berada di Stasiun 11, yaitu 3.36 ppm. Namun hasil analisis menunjukkan untuk Stasiun-Stasiun yang lain memilik kandungan DO yang relatif seragam, yaitu berkisar $2.4 \mathrm{ppm}-2.56$ ppm. Sumber utama oksigen terlarut dalam air laut adalah udara melalui proses difusi dan proses fotosintesis. Nilai baku mutu DO menurut Kementerian Lingkungan Hidup untuk kadar DO dalam suatu perairan $>5$

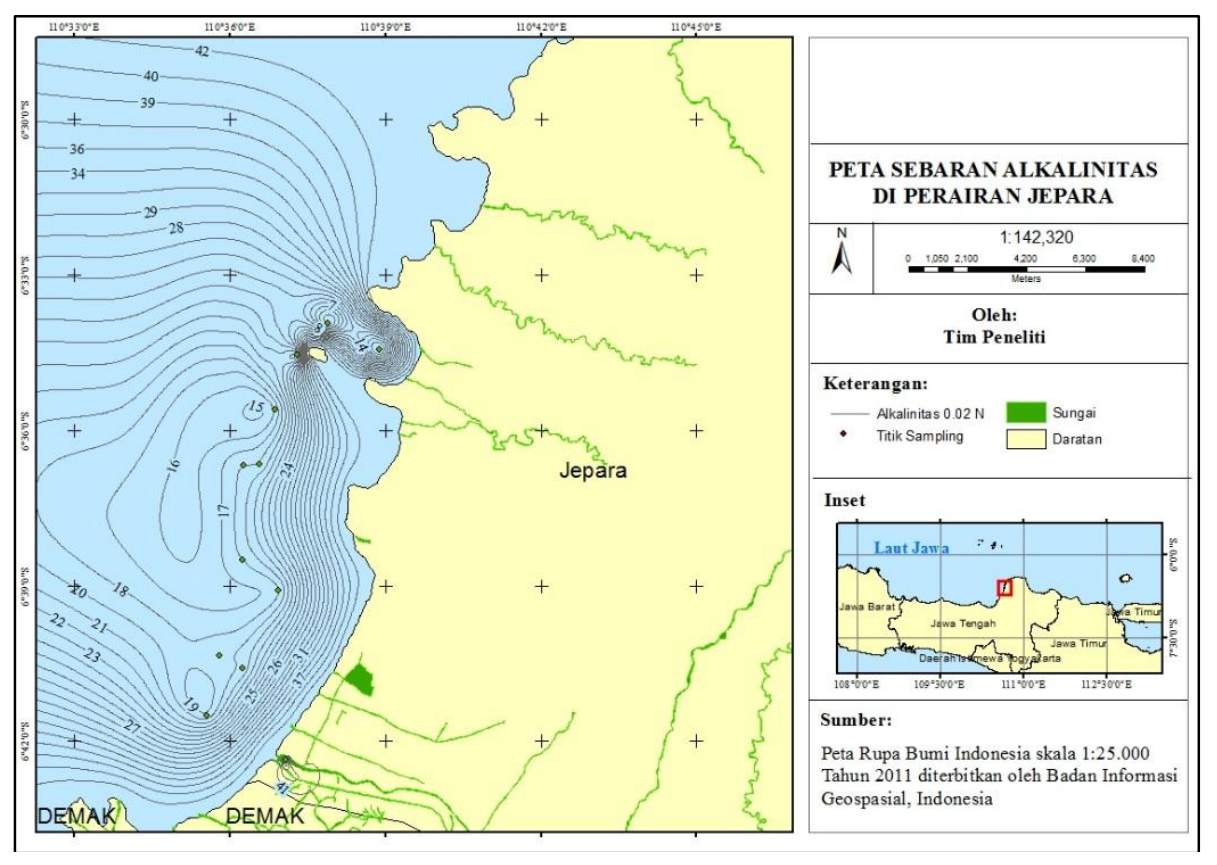

Gambar 5. Peta Sebaran Alkalinitas di Perairan Jepara.

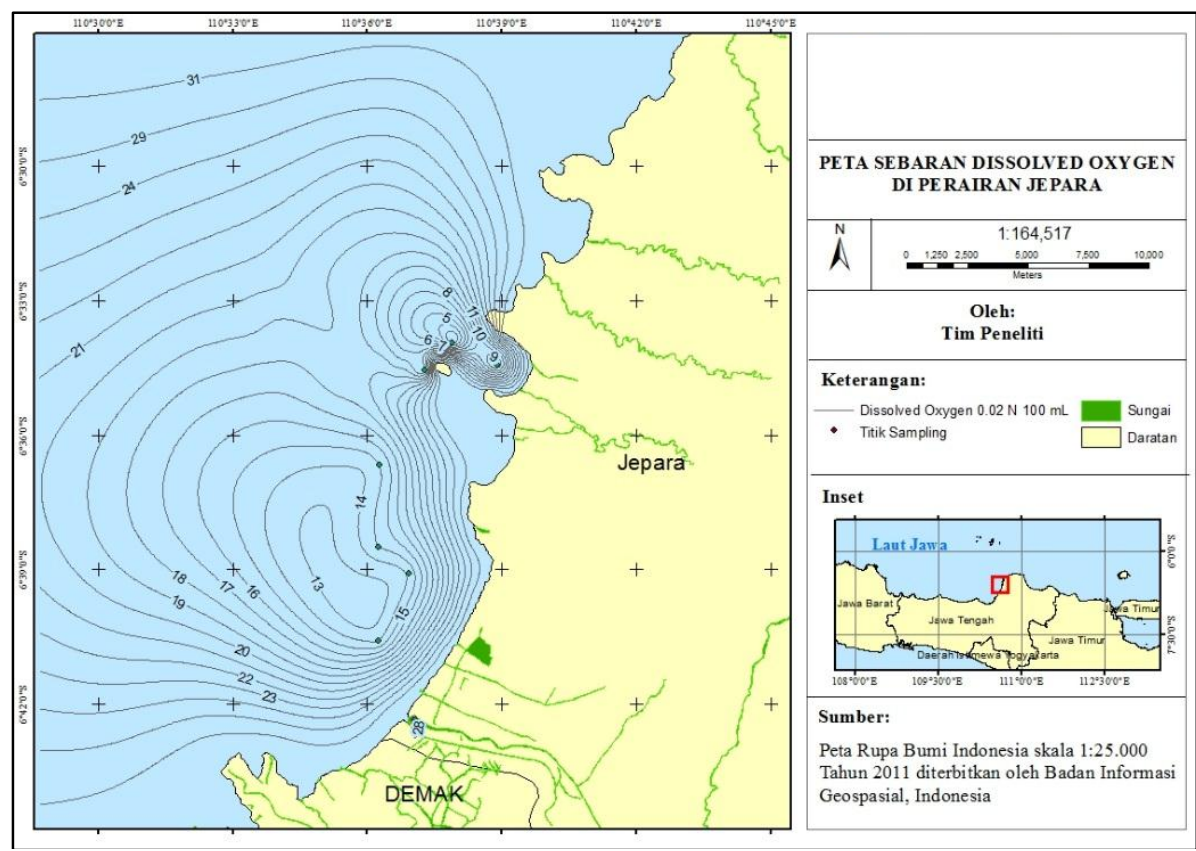

Gambar 6. Peta Sebaran Dissolved Oxygen (DO) di Perairan Jepara 


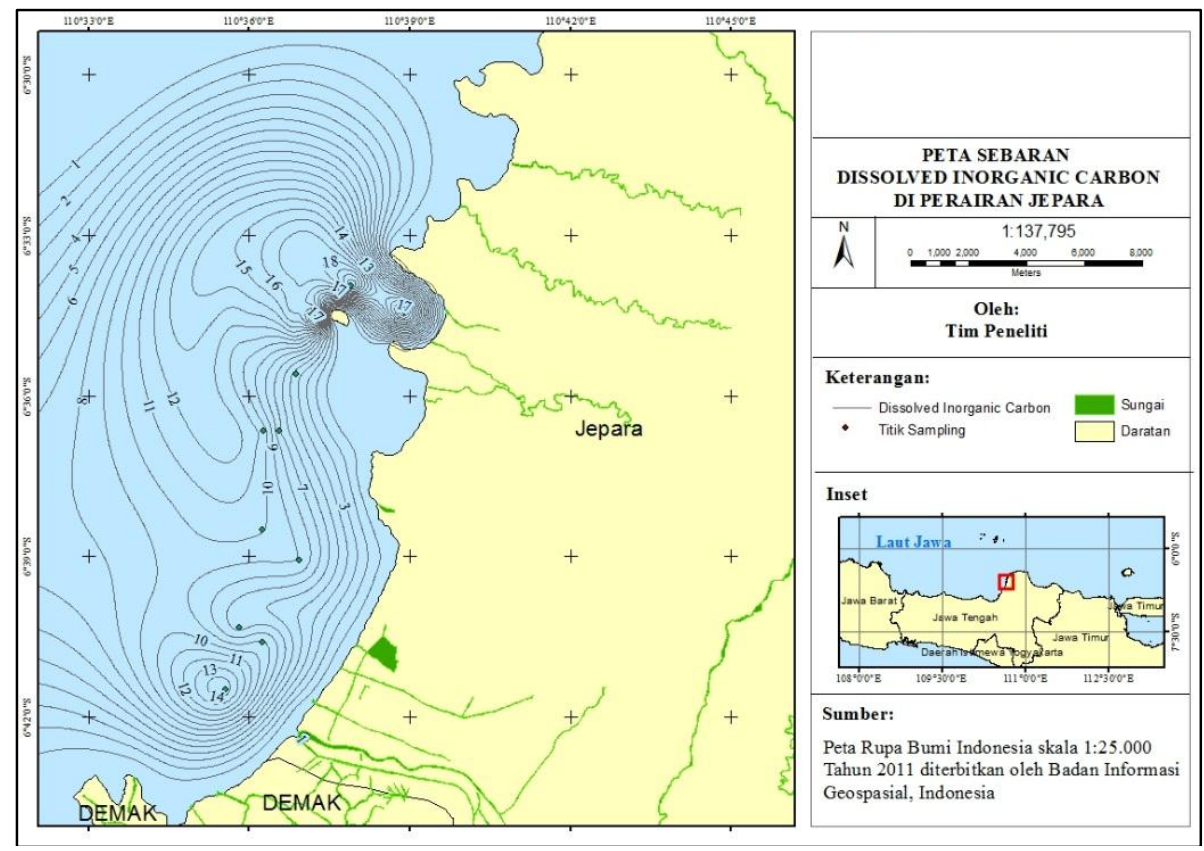

Gambar 7. Peta Sebaran $\mathrm{CO}_{2}$ Bebas di Perairan Jepara.

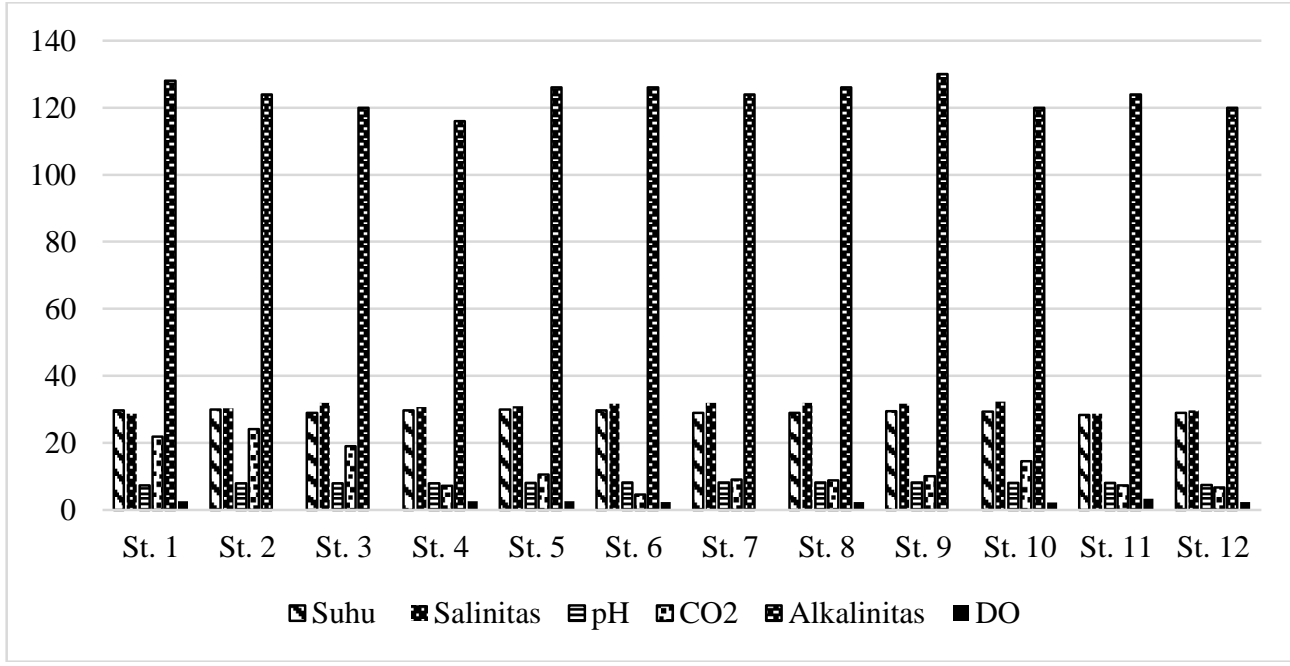

Gambar 8. Grafik Perbandingan nilai temperatur, salilinitas, $\mathrm{pH}$, Alkalinitas, $\mathrm{DO}$, dan $\mathrm{CO}_{2}$ Bebas dapat untuk masing-masing stasiun di Perairan Jepara.

ppm (KMNLH, 2004) sehingga perairan Jepara merupakan perairan yang kurang subur dikarenakan kandungan DO dibawah 5 ppm. Rendahnya kandungan DO kemungkinan karena masuknya bahan - bahan organik ke perairan Jepara sehingga membutuhkan oksigen yang banyak untuk menguraikannya. Selain itu, respirasi biota yang menghasilkan karbondioksida dan pelepasan oksegen ke udara menyebabkan berkurangnya kadar DO di perairan.

\section{Hasil Analisis $\mathrm{CO}_{2}$}

Analisis $\mathrm{CO}_{2}$ yang terkandung dalam air laut dilakukan terhadap sampel air laut di 12 titik stasiun. $\mathrm{CO}_{2}$ bebas diukur dengan menggunakan metode titrasi dengan menggunakan $\mathrm{NaOH} 0.02 \mathrm{~N}$. Hasil analisis sampel tersebut digunakan untuk membuat peta pola sebaran $\mathrm{CO}_{2}$ bebas di Perairan Jepara. Peta sebaran $\mathrm{CO}_{2}$ bebas di Perairan Jepara diperlihatkan pada Gambar 7.

Dari hasil analisis di laboratorium terhadap 12 sampel air laut Perairan Jepara, menunjukkan bahwa kandungan $\mathrm{CO}_{2}$ berkisar antara $4.6 \mathrm{ppm}-$ $24.1 \mathrm{ppm}$. Stasiun 1 dan Stasiun 2 yang terletak di dekat muara Sungai Serang memiliki kandungan $\mathrm{CO}_{2}$ yang lebih besar dibandingkan StasiunStasiun lainnya. Stasiun 1 berada di muara sungai Serang dengan nilai $\mathrm{pH}$ 7,37 sedangkan stasiun 2 
memiliki pH sebesar 7,96. Mackereth et al., (1989) mengungkapkan bahwa kondisi $\mathrm{pH}$ berkaitan erat dengan karbondioksida hal ini dikarenakan semakin tinggi $\mathrm{pH}$ maka kadar karbondioksida akan semakin rendah. Kadar karbondioksida merupakan hasil dari proses respirasi. Karbondioksida bebas dilepaskan dan bereaksi dengan air membentuk asam karbonat yang kemudian direduksi menjadi bikarbonat dan karbonat menjadikan $\mathrm{pH}$ menjadi rendah.

Perbandingan nilai temperatur, salinitas, $\mathrm{pH}$, Alkalinitas, DO, dan $\mathrm{CO}_{2}$ Bebas dapat untuk masing-masing stasiun dapat dilihat pada gambar 8. Analisis terhadap hubungan antar parameter telah dijelaskan di atas.

\section{KESIMPULAN}

Berdasarkan hasil penelitian di Perairan Jepara diperoleh kesimpulan sebagai berikut bahwa semua stasiun kecuali stasiun 11 memiliki nilai temperatur berkisar antara $29-30^{\circ} \mathrm{C}$, hal ini dikarenakan pengukuran berada di perairan terbuka dan dekat dengan daratan sehingga energi matahari lebih efektif meningkatkan temperatur air laut.Nilai salinitas terendah berada di Stasiun 1 yang letaknya berada di mulut muara Sungai Serang dengan nilai $28.7 \%$, hal ini di karenakan adanya masukan air tawar yang memiliki salinitas yang rendah.Kandungan DO yang rendah berkisar $2.4 \mathrm{ppm}-2.56 \mathrm{ppm}$ dikarenakan masuknya bahanbahan organik ke perairan Jepara sehingga membutuhkan oksigen yang banyak untuk menguraikannya. Alkalinitas berkaitan erat dengan $\mathrm{pH}$ apabila nilai alkalinitas tinggi maka nilai $\mathrm{pH}$ akan semakin tinggi. Semakin tinggi $\mathrm{pH}$ maka kadar karbondioksida akan semakin rendah.Hasil analisis di laboratorium terhadap 12 sampel air laut Perairan Jepara, menunjukkan bahwa kandungan $\mathrm{CO}_{2}$ berkisar antara $4.6 \mathrm{ppm}-24.1 \mathrm{ppm}$. Stasiun 1 dan Stasiun 2 yang terletak di dekat muara Sungai Serang memiliki kandungan $\mathrm{CO}_{2}$ yang lebih besar dibandingkan Stasiun-Stasiun lainnya.

\section{DAFTAR PUSTAKA}

Borges, A.V. 2005. Do we have enough pieces of the jigsaw to integrate $\mathrm{CO} 2$ fluxes in the coastal ocean. Estuaries. 28 (1):3-27.

Borges, A. V., B. Delille, and M. Frankignoulle. 2005. Budgeting Sinks and Sources of $\mathrm{CO}_{2}$ in the Coastal Ocean: Diversity of Ecosystems Counts. Geophysical Research Letters, 32, L14601, doi:10.1029/2005GL023053.

Brotowijoyo, M. D., Dj. Tribawono., E. Mulbyantoro., 1995. Pengantar Lingkungan
Perairan dan Budidaya Air. Liberty: Yogyakarta.Cai, W.J., Dai, M., and Wang, Y. 2006. Air-Sea Exchange of Carbon Dioxide in Ocean Margins : A Province Based Synthesis. Geophysical Research Letters, Vol.33:L12603.doi: 10.1029/2006GL026219.

Giggenbach, W.F. \& R.L. Goguel. 1989. Collection and analysis of geothermal and volcanic water and gas discharges. Chemistry Division. Department of Scientific and Industrial Research. Petone. New Zeland: 81 pp.

Grasshoff, K. 1976. Methods of seawater analysis. Verlag Chemie,Weinheim. New York: 307 pp.

IPCC, 2001. The carbon cycle and atmospheric carbon dioxide. The scientific basis. In Climate change. Hal : $185-237$.

IPCC, 2007. The Physical Science Basis Contribution of Working Group I to the Fourth Assessment Report of the Intergovernmental Panel. in Climate Change. $996 \mathrm{pp}$.

Nababan, Bisman dan Kristina Simamora. 2012. Variabilitas Konsentrasi Klorofil-A dan Suhu Permukaan Laut di Perairan Natuna. Jurnal Ilmu dan Teknologi Kelautan Tropis. 4(1):121-134.

Mackereth, F.J.H., Heron, J. and Talling, J.F., 1989. Water Analysis: Some Revised Methods for Limnologists. Freshwater Biological Association, Scientific Publication, No. 36, Cumbria and Dorset, England, $120 \mathrm{pp}$.

Suyarso. 1997. Data dan analisis data oseanologi Laut Cina Selatan. Dalam: Suyarso (Ed.). Atlas oseanologi Laut Cina Selatan. Puslitbang Oseanologi-LIPI Jakarta. 17-20pp

Takahashi, T., S.C. Sutherland, C. Sweeney, A. Poisson, N. Metzl, B.Tilbrook, N. Bates, R. Wanninkhof, R.A. Feely, C. Sabine, J.Olafsson \& Y. Nojiri, 2002. Global Sea-Air $\mathrm{CO} 2$ Flux Based on Climatological Surface Oceanp $\mathrm{PCO}_{2}$ and Seasonal Biological and Temperature Effects. Deep-Sea Research II, 49:1601-1622.

Wang, Z. H. A., and W. J. Cai. 2004. Carbon Dioxide Degassing and Inorganic Carbon Export From A Marsh-Dominated Estuary (the Duplin River): A marsh $\mathrm{CO}_{2}$ pump, Limnol. Oceanograp. 49:341-354. 